\title{
The status of the Sumatran orang-utan Pongo abelif: an update
}

\author{
S. A. Wich, I. Singleton, S. S. Utami-Atmoko, M. L. Geurts, H. D. Rijksen and C. P. van Schaik
}

\begin{abstract}
The Sumatran orang-utan Pongo abelii is categorized as Critically Endangered on the 2002 IUCN Red List. Although several reports have suggested that the species occurs in the region to the south of Lake Toba in Sumatra, Indonesia, their distribution is poorly known. In order to determine whether orang-utans still occur in this region we surveyed areas in which orangutans have been reported as well as a number of other forested areas. Orang-utan signs were found in only two areas. This indicates that habitat loss and hunting
\end{abstract}

have recently caused local extinctions. We combine these results with other available information to provide a summary of the current distribution of P. abelii in Sumatra and, based on our surveys, previous population estimates, and estimates of losses, we speculate that only c. 3,500 orang-utans still occur in the wild in Sumatra at the end of 2002.

Keywords Indonesia, Lake Toba, orang-utan, Pongo abelii, Primates, Sumatra.

\section{Introduction}

Orang-utans (Pongo spp.) are the only species of great ape found in South-east Asia. Historically their distribution ranged from southern China to the Indonesian island of Java (Hooijer, 1948; von Koeningswald, 1982; Bacon \& Long, 2001). Today they occur only on the islands of Borneo and Sumatra. Until recently, two subspecies of orang-utan were recognized: Pongo pygmaeus pygmaeus in Borneo, and Pongo pygmaeus abelii in Sumatra. However, as a result of genetic studies the populations on the two islands are now regarded as two distinct species: P. pygmaeus in Borneo and P. abelii in Sumatra (Xu \& Arnason, 1996; Groves, 1999).

Throughout their current range the continued survival of both species is threatened; the Bornean orang-utan is

S. A. Wich (Corresponding author) Utrecht University, Behavioural Biology, P.O. Box 80086, 3508 TB, Utrecht, The Netherlands.

Email: s.a.wich@bio.uu.nl

I. Singleton Sumatran Orang-utan Conservation Programme, P.O. Box 1472, Medan 20001, Sumatera Utara, Indonesia.

S. S. Utami-Atmoko Universitas Nasional, JI. Sawo Manila, Ps. Minngu, Jakarta, Indonesia, and Utrecht University, Behavioural Biology, P.O. Box 80086, 3508 TB, Utrecht, The Netherlands.

M. L. Geurts Utrecht University, Behavioural Biology, P.O. Box 80086, 3508 TB, Utrecht, The Netherlands.

H. D. Rijksen Federation for International Nature Protection, Sparrenbos 19, 6705 BB Wageningen, The Netherlands.

C. P. van Schaik Biological Anthropology and Anatomy, Duke University, Box 90383, Durham, NC 27708-0383, USA

Received 14 January 2002. Revision requested 5 June 2002. Accepted 26 September 2002 categorized on the 2002 IUCN Red List as Endangered and the Sumatran orang-utan as Critically Endangered (IUCN, 2002). The main threats to their survival are habitat loss and illegal trade (Rijksen \& Meijaard, 1999; van Schaik et al., 2001). Orang-utans are specialists of old-growth forest, and favour lowland and swamp forests but also occur in foothill forests (Djojosudharmo \& van Schaik, 1992; van Schaik et al., 1995; Rijksen \& Meijaard, 1999; Buij et al., 2002). Considering the amount of forest lost in Sumatra over the last two decades, it is likely that within a few years little natural forest habitat will remain (Holmes, 2000).

To map the distribution of orang-utans, Rijksen \& Meijaard (1999) conducted field surveys and an extensive and detailed summary of the literature. They concluded that the distribution of the Bornean orang-utan was relatively well known but that, with the exception of the Leuser Ecosystem, little information was available on the status of surviving populations of Sumatran orang-utans. Their estimates of the populations in 1998 were 23,143 on Borneo and c. 12,770 on Sumatra. Their estimate for Sumatra included data from incidental reports (Heynsius-Viruli \& van Heurn, 1935; Wilson \& Wilson, 1973; Rijksen, 1978) for areas to the south of Lake Toba (Fig. 1), an area where it was generally believed orang-utans no longer occurred (Carpenter, 1938; Whitten et al., 1984). Remains found in central Sumatra (Hooijer, 1948) indicate that historically orang-utans did occur in the region to the south of Lake Toba and, as the species also occurred in Java (Rijksen \& Meijaard, 1999), it most likely occurred throughout Sumatra.

Van Schaik et al. (2001) concluded that c. 4,500 Sumatran orang-utans still existed within the Leuser Ecosystem and that the species was disappearing at a rate in excess 


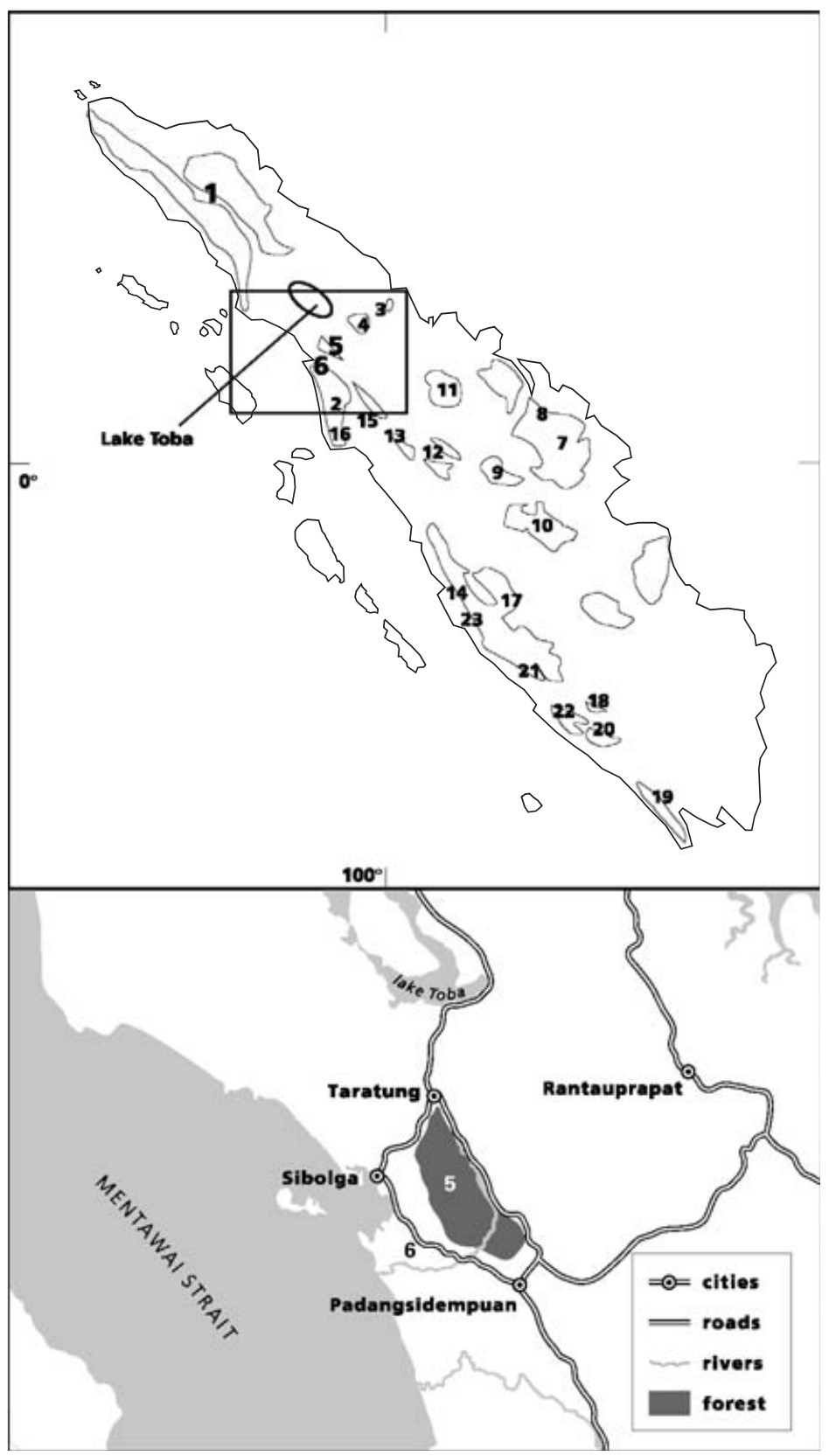

Fig. 1 Sumatra (upper map) with forested areas outlined; the numbers refer to the locations in Table 1. The rectangle indicates the location of the enlarged lower map, with the two areas where we found signs of orang-utans: the Padangsidempuan,

Tarutung, Sibloga area (no. 5) and the Lumut coastal swamps (no. 6). of 1,000 individuals per year. Rijksen \& Meijaard (1999) suggested that if the occurrence of Sumatran orang-utan populations further south could be confirmed this would provide an additional opportunity for the species' conservation.

In this paper we update the available information on the current distribution of orang-utans on Sumatra with new information from recent field surveys in the region to the south of Lake Toba. We combine these findings with published and unpublished distribution data from other areas in Sumatra to provide a new estimate of the population of $P$. abelii in Sumatra.

\section{Methods}

Two field surveys were conducted in forest areas to the south of Lake Toba, from 18 August to 4 September 2000, by SAW, SSUA and IS, and from 21 May to 25 June 2001, by SAW and MLG. To investigate the possible presence of orang-utans we concentrated on large forest blocks in which Rijksen \& Meijaard (1999) had previously reported orang-utan presence. To obtain the most recent information on the distribution of forests we used a vegetation map prepared from satellite images taken during 1998-2000 (Stibig et al., 2001). In addition to our 
own field surveys, we also collated recent information from researchers and forest officials in other parts of Sumatra. In this way we were able to obtain information on orang-utan presence or absence in most of the remaining large forest blocks to the south of Lake Toba.

Surveys of 1-3 days were made in 12 forest blocks (Table 1, Fig. 1). We searched for three definitive signs: direct sightings, sightings of sleeping nests, and characteristic vocalisations. For the purpose of our survey verbal reports of orang-utan sightings by local people were not accepted as evidence of occurrence. We surveyed forest blocks irrespective of what the local inhabitants reported, and only used one or more of the three definitive signs as evidence of orang-utan presence.

\section{Results}

In most of the areas surveyed little suitable orang-utan habitat remained, and we also found that several areas that appeared forested on the satellite images for
1998-2000 had already undergone heavy logging (e.g. the Bantahan and Sungai Pagar areas, Fig. 1) or were already deforested and had been burnt in preparation for oil palm plantations (e.g. Kuala Mahatu, Fig. 1). In particular we observed massive and ongoing forest destruction in the province of Riau. In virtually all the coastal swamp forest areas visited (Table 1, Fig. 1) the forest was largely destroyed, although we found a few areas of swamp forest in the Danau Bawah Reserve still in relatively good condition.

In most of the areas surveyed we could not confirm earlier reports of orang-utans. We were able to confirm orang-utan presence, by observations of nests at densities of c. $0.5 \mathrm{~km}^{-2}$, in only two areas: Padangsidempuan, Tarutung and Sibolga, and Lumut coastal swamps (Fig. 1). The former is an area of largely hilly ground lying between the three towns. Within this more or less continuous forest block we found nests in and near the Cagar Alam Sibual-buali conservation area and along the road from Sibolga to Tarutung. According to the satellite image there is $c .740 \mathrm{~km}^{2}$ of forest within

Table 1 The occurrence of orang-utans in the 12 areas of forest surveyed in the region to the south of Lake Toba, and in 11 other forest areas on Sumatra. The numbers refer to the locations in Fig. 1.

\begin{tabular}{|c|c|c|c|c|c|}
\hline No & Location & Forest type & Orang-utan occurrence & Province & Source \\
\hline 1 & $\begin{array}{l}\text { Leuser and } \\
\text { surroundings }\end{array}$ & Swamp-Montane & Present & Aceh/Sumatra Utara & $\begin{array}{l}\text { Rijksen \& Meijaard (1999), } \\
\text { van Schaik et al. (2001) }\end{array}$ \\
\hline 2 & Angkola & Swamp, Lowland-Montane & Absent & Sumatra Utara & This paper \\
\hline 3 & Barumun & Hill-Montane & Absent & Sumatra Utara & This paper \\
\hline 4 & Gunung Tua & Hill-Sub-Montane & Absent & Sumatra Utara & This paper \\
\hline 5 & $\begin{array}{l}\text { Padangsidempuan, } \\
\text { Tarutung, Sibolga } \\
\text { area }\end{array}$ & Hill-Montane & Present & Sumatra Utara & This paper \\
\hline 6 & $\begin{array}{l}\text { Lumut coastal } \\
\text { swamps }\end{array}$ & Swamp-Hill & Present & Sumatra Utara & This paper \\
\hline 7 & Teluk Kuantan & Swamp-Hill & Absent & Riau & Yanuar pers. comm. \\
\hline 8 & Danau Bawah & Swamp & Absent & Riau & This paper \\
\hline 9 & Sungai Pagar & Lowland & Absent & Riau & This paper \\
\hline 10 & $\begin{array}{l}\text { Bukit Tiga Puluh } \\
\text { National Park }\end{array}$ & Lowland-Hill & Absent & Riau & P. Pratje, pers. comm. \\
\hline 11 & Kuala Mahatu & Lowland & Absent & Riau & This paper \\
\hline 12 & Ulu Rokan & Lowland-Montane & Absent & Riau/Sumatra Barat & This paper \\
\hline 13 & $\begin{array}{l}\text { Rimba Panti \& } \\
\text { Gn. Talamau }\end{array}$ & Lowland-Montane & Absent & Sumatra Barat & This paper \\
\hline 14 & Tapan & Swamp & Absent & Sumatra-Barat & Yanuar, pers. comm. \\
\hline 15 & Sigantang & Hill-Montane & Absent & $\begin{array}{l}\text { Sumatra Utara and } \\
\text { Sumatra Barat }\end{array}$ & This paper \\
\hline 16 & Bantahan & Swamp, Lowland-Hill & Absent & Sumatra Utara and Barat & This paper \\
\hline 17 & $\begin{array}{l}\text { Kerinci Seblat } \\
\text { National Park }\end{array}$ & Lowland-Montane & Absent & $\begin{array}{l}\text { Sumatra Barat, Selatan, } \\
\text { Jambi, Bengkulu }\end{array}$ & $\begin{array}{l}\text { Yanuar \& Azwar, } \\
\text { pers. comm. }\end{array}$ \\
\hline 18 & Muara-Enim-Lahat & Lowland & Absent & Sumatra-Selatan & Mistar, pers. comm. \\
\hline 19 & $\begin{array}{l}\text { Bukit Barisan Selatan } \\
\text { National Park }\end{array}$ & Lowland-Montane & Absent & Bengkulu & O'Brien \& Kinnaird (1996) \\
\hline 20 & Bukit Nanti & Hill-Montane & Absent & Benkulu & Istiadi (1997) \\
\hline 21 & Ketaun & Lowland & Absent & Bengkulu & Azwar, pers. comm. \\
\hline 22 & Tais & Lowland-Hill & Absent & Bengkulu & Azwar, pers. comm. \\
\hline 23 & Muko-muko & Lowland & Absent & Bengkulu & Yanuar, pers. comm. \\
\hline
\end{tabular}


this area. Lumut coastal swamps is an area of already logged coastal swamp forest near to the village of Lumut and north of the Batang Toru river.

\section{Discussion}

Despite the existence of a number of old accounts and some relatively recent reports (Istiadi, 1997; Rijksen \& Meijaard, 1999), we were only able to confirm the presence of orang-utans in two areas in the region to the south of Lake Toba: the Sibolga, Tarutung and Padangsidempuan area and the Lumut coastal swamps. Although our surveys were relatively short, orang-utans usually leave evidence of their presence in an area; this is particularly true for their nests, which decay only slowly (van Schaik et al., 1995; Singleton, 2000). As a consequence, we are confident that any orang-utan populations in the areas surveyed would have been detected.

Some caution is required when using nests to confirm the presence of orang-utans. This is because there are other species (e.g. large raptors, giant squirrel Ratufa affinis, and sun bears Helarctos malayanus) that also make large nests that could potentially be mistaken for those of orang-utans by inexperienced observers. Nests of raptors can easily be distinguished from orang-utan nests as they consist mainly of small twigs, usually without leaves (MacKinnon \& Phillipps, 1993), and are normally located high in the crown of large emergent trees. Giant squirrels bite off only small branches and place them to produce a round ball-like nest (S. S. Utami, pers. obs.), which makes it easily distinguishable from orangutan nests. Bear nests are distinguishable from orang-utan nests because they are usually situated near the tree trunk, are less compact and flattened than an orang-utan nest, and the nesting-tree often contains signs of bear claw marks (G. G. Fredriksson, pers. comm.; Meijaard, 1999). In addition, Meijaard (1999) reports that sun bears rarely build nests in primary forests. Orang-utan nests almost invariably contain at least some relatively large, broken or bent branches (MacKinnon, 1974; Rijksen, 1978). The animal invariably breaks at least one or more large branches inwards, producing a nest that is flat-topped in appearance. Orang-utan nests are also more commonly positioned on the side branches of medium-sized trees, or in the top of smaller, sub-canopy trees.

Orang-utans were historically found throughout Sumatra (Rijksen \& Meijaard, 1999), and until recently in several areas such as Rimba Panti/Gunung Talamau and certain parts of the coastal swamps on the west coast of Sumatra (Heynsius-Viruli \& van Heurn, 1935). The causes of their disappearance in these and other areas can only be continued habitat loss and hunting.
In the Rimba Panti area, where orang-utans still occurred in 1983 (Y. Laumonier, pers. comm.), local villagers informed us that several areas of lowland forest had been converted into agricultural land during the last 20 years. As orang-utans favour lowland forests (Djojosudharmo \& van Schaik, 1992; Rijksen \& Meijaard 1999; Buij et al. 2002) this indicates that much of their habitat has been lost. Most of the remaining forests in this area now lie above 1,000 $\mathrm{m}$ altitude. Because orangutans require large home ranges (800-1,500 ha for females and $>3,000$ ha for males) even in productive peat swamp forests (Singleton \& van Schaik, 2001), the relatively small area of lowland forest that remains in the Rimba Panti/Gunung Talamau area is probably no longer sufficient to support a viable orang-utan population. In addition a main road also dissects the area, facilitating access, and it is therefore likely that poaching has been severe. The same is likely to have occurred in many other areas. Surveys by one of us (CvS) in 1998 failed to detect orang-utans in coastal swamp forest to the west and south-west of Lake Toba in an area of high hunting pressure, despite a reasonable amount of suitable habitat still being available and the fact that orang-utans were formerly reported in the area (Heynsius-Viruli \& van Heurn, 1935).

In the two areas where we found evidence of orangutans, nest density was similar to that found further north in Aceh. Local people provided accurate descriptions of the physical appearance of orang-utans and also of their arboreal habits. Some mentioned that they had heard vocalizations, and an orang-utan was seen in one of the areas, Batang Toru, during a recent bird survey (Wibowo, pers. comm.).

The future of orang-utan populations in the region surveyed is bleak because the protected areas in which they are still found are too small for their long term survival. The largest, with an area of c. 5,000 ha, is the Cagar Alam Sibual-buali conservation area. However, the area is sufficient to support only c. 12 individuals (c.f. Singleton, 2000; Singleton \& van Schaik, 2001) and, according to a local forestry offical, some parts are affected by illegal logging. A possible solution to the lack of sufficiently large areas of suitable habitat, successfully pursued within the Leuser Ecosystem since the early 1990s (Rijksen \& Griffiths, 1995; M. Griffiths, pers. comm.), would be the re-designation of production forests to wildlife reserves, if sufficient political pressure could be applied. However, even in the Leuser Ecosystem illegal logging and poaching continue (Van Schaik et al., 2001; Robertson \& van Schaik, 2001).

Where remnant populations of orang-utans survive in forest patches that are too small or too severely logged, individuals could be translocated to more suitable areas or additional food could be supplied until such time 
as the patches can be restored and connected to form larger forested units. There is currently a programme to reintroduce captive orang-utans to the Bukit Tiga Puluh National Park (Fig. 1), an area in which orang-utans no longer occur but that has suitable orang-utan habitat (Pratje, 2000).

Rijksen \& Meijaard's (1999) estimates of the number of orang-utans in certain areas require revision. They estimated that in 1997 a total of c. 12,770 orang-utans remained in Sumatra. Of the areas that they included in their estimates our surveys have indicated that at least five no longer contain orang-utans, and we therefore conclude that the total estimate must be reduced to c. 10,800 . However, this number must be further reduced by an estimate of the expected loss of orang-utans due to habitat loss, fragmentation and hunting. If we accept the conclusion of van Schaik et al. (2001) that c. 1,000 orang-utans annually were being lost from the Leuser Ecosystem alone between 1993 and 1999, and because we have no evidence that this trend has changed, our 'best guess' for the total number of orang-utans that remain in the wild in Sumatra at the end of 2002 is c. 3,500.

\section{Acknowledgements}

We gratefully acknowledge the co-operation and support of the Indonesian Institute of Science (LIPI, Jakarta) and the Indonesian Nature Conservation Service for giving us permission to work in Indonesia. We also thank the Leuser management unit, especially Mike Griffiths, for providing logistical support. We are also grateful for the financial support of the Golden Ark Foundation, and we thank the European Commission-Joint Research Centre/ Global Vegetation Monitoring Unit for their permission to let us use their SPOT vegetation satellite mosaic of Sumatra. Perry van Duijnhoven is acknowledged for helping out in Indonesia. We also thank Azwar, Anjar Rafiastanto, Mistar, and Yanuar for generously sharing information with us.

\section{References}

Bacon, A.M. \& Long, V.T. (2001) The first discovery of a complete skeleton of a fossil orang-utan in a cave of Hao Binh province. Journal of Human Evolution, 41, 227-242.

Buij, R., Wich, S.A., Lubis, A.H. \& Sterck, E.H.M. (2002) Seasonal movements of the Sumatran orangutan (Pongo pygmaeus abelii) and consequences for conservation. Biological Conservation, 107, 83-87.

Carpenter, C.R. (1938) A survey of wildlife conditions in Atjeh, North Sumatra. Nederlandse Commissie voor Internationale Natuurbescherming, 12, 1-33.

Djojosudharmo, S. \& van Schaik, C.P. (1992) Why are orangutans so rare in the highlands? Tropical Biodiversity, $\mathbf{1}$ $11-22$.
Groves, C.P. (1999). The taxonomy of orang-utans. In Orangutan Action Plan (ed. C. Yeager), pp. 27-30. WWF, Jakarta, Indonesia.

Heynsius-Viruli, A. \& van Heurn, F.C. (1935) Overzicht van de uit Nederlandsch-Indië ontvangen gegevens, met biologische aantekeningen omtrent de betreffende diersoorten. Nederlandse Commissie voor Internationale Natuurbescherming. Supplement op Med, 10, 36-40.

Holmes, D. (2000) Deforestation in Indonesia. A Review of the Situation in 1999. World Bank, Jakarta, Indonesia.

Hooijer, D.A. (1948) Prehistoric teeth of man and of the orangutan from Central Sumatra, with notes on the fossil orang-utan from Java and Southern China. Zoologische Mededeelingen, Rijksmuseum Leiden, 1-175.

Istiadi, Y. (1997) Indikasi Keberadaan dan Pengambilan Sampel Genetika Orangutan (Pongo pygmaeus abelii) di Sumatera. Pusat Studi Biodiversitas dan Konservasi Universitas Indonesia, Jakarta, Indonesia.

IUCN (2002) 2002 IUCN Red List of Threatened Species. http:/ / www.redlist.org [accessed 17 October 2002].

MacKinnon, J.R. (1974) The behaviour and ecology of wild orang-utans. Animal Behaviour, 22, 3-74.

MacKinnon, J.R. \& Phillipps, K. (1993) A Field Guide to the Birds of Borneo, Sumatra, Java, and Bali. Oxford University Press, Oxford, UK.

Meijaard, E. (1999) Ursus malayanus, the Neglected Malayan Sunbear. Nederlandsche Commissie voor Internationale Natuurbescherming, Leiden, Netherlands.

O’Brien, T.G. \& Kinnaird, M.F. (1996) Birds and mammals of the Bukit Barisan Selatan National Park. Oryx, 30, 207-217.

Pratje, P. (2000) Fruit Availability in the Bukit Tigapuluh National Park as an Estimator of Orang-utan Carrying Capacity. Unpublished Report of the The Frankfurt Zoological Society and the Paneco Foundation.

Rijksen, H.D. (1978) A Field Study on Sumatran Orangutans (Pongo pygmaeus abelli Lesson, 1827). H. Veenman \& Zonen, Wageningen, Netherlands.

Rijksen, H.R. \& Griffiths, M. (1995) Masterplan for the Leuser Development Programme. Unpublished Report, Wageningen, Netherlands.

Rijksen, H.D. \& Meijaard, E. (1999) Our Vanishing Relative: The Status of Wild Orangutans at the Close of the Twentieth Century. Kluwer Academic Publishers, Dordrecht, Netherlands.

Robertson, J.M.Y. \& van Schaik, C.P. (2001). Causal factors underlying the dramatic decline of the Sumatran orang-utan. Oryx, 35, 26-38.

Singleton, I. (2000). Ranging behaviour and seasonal movements of Sumatran orangutans (Pongo pygmaeus abelii) in Swamp Forests. PhD thesis, University of Kent, Canterbury, UK.

Singleton, I. \& van Schaik, C.P. (2001) Orangutan home range size and its determinants in a Sumatran swamp forest. International Journal of Primatology, 22, 877-911.

Stibig, H-J., Malingreau, J.P. \& Beuchle, R. (2001) New possibilities of regional assessment of tropical forest cover in insular Southeast Asia using SPOT-Vegetation satellite image mosaics. International Journal of Remote Sensing, 22, 503-505.

Van Schaik, C.P., Azwar \& Priatna, D. (1995) Population estimates and habitat preferences of orangutans based on line transects of nests. In The Neglected Ape (eds R.D. Nadler, B.M.F. Galdikas, L.K. Sheeran \& N. Rosen), pp. 129-147. Plenum Press, New York, USA. 
Van Schaik, C.P., Monk, K.A. \& Robertson, J.M.Y. (2001) Dramatic decline in orang-utan numbers in the Leuser Ecosystem, Northern Sumatra. Oryx, 35, 14-25.

von Koeningswald, G.H.R. (1982) Distribution and evolution of the orang utan, Pongo pygmaeus (Hoppius). In The Orang utan its Biology and Conservation (ed L.E.M. de Boer), pp. 1-15. Dr. W. Junk, The Hague, Netherlands.

Whitten, A.J., Damanik, S.J., Anwar, J. \& Hisyam, N. (1984) The Ecology of Sumatra. Gajah Mada University Press, Bandung, Indonesia.

Wilson, C.C. \& Wilson, W. L. (1973). Census of Sumatran primates. Unpublishned Final Report to LIPI (Indonesian Institute of Science), Jakarta, Indonesia.

Xu, X. \& Arnason, U. (1996) The mitochondrial DNA molecule of Sumatran orangutan and a molecular proposal for two (Bornean and Sumatran) species of orangutan. Journal of Molecular Evolution, 43, 431-437.

\section{Biographical sketches}

Serge Wich is currently conducting research on vocalizations and sexual selection in Thomas' langur Presbytis thomasi, and is involved in setting up a long-term database for orangutan data collected at Ketambe in the Leuser Ecosystem, Sumatra, over the past 30 years.

Ian Singleton studied orang-utans for several years in the swamp forests of Suaq Balimbing in Aceh, and is now working on a project to establish a programme to reintroduce captive orang-utans into forested areas on Sumatra.

Sri Suci Utami Atmoko conducted a long-term study of orang-utans at Ketambe and is currently also involved in setting up the Ketambe database. 